\title{
Development of a Rapid Cell-free Method for Cytotoxicity Assessment of Vapor Phase of Cigarette Smoke*
}

\author{
by \\ Xavier Cahours, Maryline Blanchet, Matthieu Dubois, and Céline Haond \\ SEITA, Imperial Tobacco Group, 4, rue André Dessaux, 45404 Fleury-les-Aubrais, France
}

\section{SUMMARY}

Currently, several in vitro tests are widely used to measure toxicological properties of mainstream smoke (Neutral Red Uptake Assay, micronucleus assay, Ames Test). These tests are necessary to assess cytotoxicity, genotoxicity, and mutagenicity, but are time consuming. This is essentially due to the preparation and the handling of cells. It is difficult to use these in vitro tests as screening method for product testing and development. For a better assessment of the cytotoxicity of the vapor phase, a rapid cell-free method has been developed. This paper describes a capillary electrophoresis cell-free method, based on the depletion of an anti-oxidant L-gamma-glutamyl-L-cysteinylglycine (GSH), applied to an aliquot of vapor phase phosphate buffered saline (PBS)-trapped cigarette smoke (as recommended for in vitro testing). The correlation between this method and the survival/viability test (Neutral Red cytotoxicity) is excellent (coefficient of correlation ( $\mathrm{r}=$ 0.99)). [Beitr. Tabakforsch. Int. 24 (2011) 157-165]

\section{ZUSAMMENFASSUNG}

Derzeit werden mehrere in vitro-Tests zur Messung der toxikologischen Eigenschaften des Hauptstromrauchs empfohlen (Neutralrot-Test, Mikronukleus-Assay, AmesTest). Diese Tests sind notwendig, um die Zytotoxizität, die Gentoxizität und die Mutagenität zu beurteilen, aber sie sind zeitaufwändig, und zwar hauptsächlich aufgrund der Vorbereitung und Handhabung der Zellen. Es ist schwierig, diese in vitro-Tests als Screening-Methoden für die Produkttestung und -entwicklung zu verwenden. Für eine bessere Beurteilung der Zytotoxizität der Gasphase wurde eine schnelle, zellfreie Methode entwickelt. Die Arbeit beschreibt eine zellfreie Kapillarelektrophorese-Methode, basierend auf der Depletion des Antioxidans' L-gamma-
glutamyl-L-cysteinylglycine (GSH) bei Anwendung auf ein Aliquot der in PBS eingeschlossenen Gasphase (wie in dem empfohlenen in vitro-Testverfahren verlangt). Die Korrelation zwischen dieser Methode und dem Überlebens/Lebensfähigkeitstest (Neutralrot-Zytotoxizität) ist ausgezeichnet $(\mathrm{r}=0,99)$. [Beitr. Tabakforsch. Int. 24 (2011) 157-165]

\section{RESUME}

Aujourd'hui, plusieurs tests in-vitro sont recommandés pour déterminer les effets toxicologiques de la fumée de cigarette (Test du rouge neutre, test des micronoyaux, test d'Ames). Ces tests sont absolument nécessaires pour mesurer la cytotoxicité, la génotoxicité et la mutagénicité, mais sont hélas très consommateur de temps. Ces temps qui proviennent essentiellement de la préparation et la manipulation des cellules, rendent difficile l'utilisation de ces tests dans des études de screening et de développement. Afin d'avoir une idée rapide de la cytotoxicité de la phase gazeuse, une méthode, sans cellule, a été mise au point. Cet article décrit cette méthode d'analyse, basée sur le principe de l'évaluation, par électrophorèse capillaire, de la déplétion d'un antioxydant, le L-gamma-glutamyl-Lcysteinylglycine (GSH), mis en contact avec un aliquot de phase gazeuse piégée dans un tampon phosphate salin (comme utilisé dans les tests in-vitro). La corrélation obtenue entre cette méthode et celle du rouge neutre est excellente $(\mathrm{r}=0.99)$. [Beitr. Tabakforsch. Int. 24 (2010) 157-165]

\section{INTRODUCTION}

In order to assess biological properties of tobacco products, various in vitro tests have been developed (1-3). 
Cytotoxicity measurement can be assessed by a cell survival/viability test (Neutral Red Uptake Assay), genotoxicity can be performed with the micronucleus assay and mutagenicity can be determined using the Ames test. These tests allow a quantitative comparison of toxicological properties of the smoke of tobacco products, but they are very time-consuming and restrictive as a screening method for new products or new filter development. It is therefore of great interest to permit the rapid screening of novel product designs or to efficiently eliminate from further consideration prototype products that may have undesirable properties before the in vitro testing stage. One of the biochemical properties of tobacco smoke which has been investigated by LEUCHTENBERGER et al. (4) was the reaction of fresh tobacco smoke with sulfhydryl groups of cysteine. Using this property, SCHERER et al. described a method based on the reaction between fresh tobacco smoke and reduced glutathione (GSH) (5). GSH, the most abundant non-protein thiol in mammalian cells, plays an important role against oxidative damage $(6,7)$. In presence of oxidizing agents GSH is transformed into oxidized GSH (GSSG), and, GSH can be also modified directly by electrophile compounds. The vapor phase of cigarette smoke contains abundant oxidizing agents $(8,9)$ and several electrophile compounds, in particular, $\alpha-\beta$ unsaturated aldehydes (10). GSH reacts easily with $\alpha-\beta$ unsaturated aldehydes without metabolic activation (11, 12). So, in light of this prior knowledge, we have developed a cell-free method based on the reaction of a GSH with PBS-trapped cigarette smoke vapor phase (as specified in in vitro testing). This paper described this novel capillary electrophoresis (CE) cell-free method. The results obtained with this $\mathrm{CE}$ method showed a strong correlation with results obtained with the conventional Neutral Red Uptake Assay. This relationship allows the use of this rapid cellfree method to assess the cytotoxicity of the vapor phase of cigarette smoke with high efficiency.

\section{EXPERIMENTAL}

\section{Chemicals}

All the chemical compounds were of analytical reagent grade and deionized water, produced with a Millipore Milli-Q water-purification system (Millipore, St Quentin en Yveline, France), was used to prepare all the solutions. Glutathione, potassium phosphate monobasic, methionine and sodium hydroxide were obtained from Sigma (SigmaAldrich, Saint Quentin Fallavier, France). Phosphate buffered saline (PBS 1x) was made up by dilution (1:10) of Dulbecco's phosphate buffered saline 10x (Eurobio, Les Ulis, France).

\section{Smoking protocol}

For at least 24 hours before smoking, we conditioned cigarettes in an environmental chamber maintained at a temperature of $22{ }^{\circ} \mathrm{C}$ with $60 \%$ relative humidity. Cigarettes were smoked on a five-port smoking machine (Borgwaldt $\mathrm{KC}, \mathrm{GmbH}$ ) according to ISO conditions (13). The puff parameters were: sine wave flow profile, $35 \mathrm{~mL}$ per puff for a 2-sec duration every $60 \mathrm{sec}$. The particulate phase of the smoke was trapped by filtration through a normalized fibre-glass filter and the vapor phase of the smoke was bubbled into a glass tube containing $10 \mathrm{~mL}$ of phosphate buffer. Five cigarettes were smoked for each determination. After the last puff, the saline solutions were stored in aliquots at $-180^{\circ} \mathrm{C}$ until the reaction with GSH.

\section{Capillary electrophoresis (CE)}

The CE analysis was performed using a P/ACE MDQ system equipped with a UV-Vis detector, automated injector and autosampler (Beckman Instruments, Fullerton, CA, USA). The CE system was fitted with a $30 \mathrm{kV}$ power supply with a current limit of $250 \mu \mathrm{A}$. The solutes were injected hydrodynamically at the cathode end of the capillary under gas pressure $(0.5 \mathrm{psi}, 5 \mathrm{~s})$. Separations were carried out at a constant temperature $\left(40^{\circ} \mathrm{C}\right)$ and detection was performed at $200 \mathrm{~nm}$. Conventional fused-silica capillaries $(67 \mathrm{~cm}(50 \mathrm{~cm}$ detection length $) \times 50 \mu \mathrm{m}$ I.D. (375 $\mu \mathrm{m}$ O.D.)) were used.

\section{Cytotoxicity assay (Neutral Red Uptake)}

Chinese Hamster Ovary Cells (CHO strain K1) were obtained from Sigma-Aldrich (ECCAC 85051005) and were maintained on Ham-F12 medium (Lonza, France) supplemented with $1 \%$ penicillin/streptomycin $(10,000$ $\mathrm{U} / \mathrm{mL}$ penicillin, $10,000 \mu \mathrm{g} / \mathrm{mL}$ streptomycin, Lonza, France), 5\% fetal calf serum, FCS (Lonza, France) for growth or $1 \%$ FCS for treatment. The cells were grown at $37{ }^{\circ} \mathrm{C}, 95 \%$ air and $5 \% \mathrm{CO}_{2}$ in a humidified incubator. $\mathrm{CHO}$ cells were chosen due to their sensitivity in previous cytotoxicity assays evaluating the activity of cigarette smoke condensate and vapor phase of cigarette smoke (14-16).

Neutral Red (NR) solution $(0.33 \%)$ was obtained from Sigma-Aldrich. The working NR solution was prepared in Dulbecco's modification of Eagles media Hams F-12 (DMEM-Hams-F12) (Lonza, France) medium just before use. To eliminate fine precipitate and dye crystals before incubation with cells, the working NR solution was filtered through a $0.22 \mu \mathrm{m}$ filter. The fixative solution was made with $10 \%$ formaldehyde (Sigma-Aldrich) and $10 \% \mathrm{CaCl}_{2}$ (Sigma-Aldrich). To extract the dye from the cells, a solvent solution was prepared with $1 \%$ acetic acid- $50 \%$ ethanol.

A chemical agent, dodecyl sulfate, SDS (Sigma-Aldrich), was used as a positive control, between 10-80 $\mu \mathrm{g} / \mathrm{mL}$ diluted in Hams-F12 supplemented with 1\% FCS.

A reference cigarette was tested in every experiment. This reference cigarette is made of US Blend style without any additional ingredient and no filter ventilation.

The cytotoxicity assay was performed using the Neutral Red Cytotoxicity Assay. It is based on the ability of a viable cell to incorporate and to accumulate a vital dye (Neutral-Red) into lysosomes. The uptake of Neutral Red is proportional to viable cells number (14-16).

Cells were plated into a 96-well tissue culture plate (Nunc) at a density of 20,000 cells per well for $24 \mathrm{~h}$. After which the media was replaced by $200 \mu \mathrm{L}$ media or $200 \mu \mathrm{L}$ media added with six concentrations of the vapor phase solution 
$(0.4,0.8,1.6,3.0,4.5$, and $6.5 \mathrm{~mL}$ of vapor $\mathrm{phase} / \mathrm{mL}$ of PBS for IC50 $<6$ and 2.5, 5.0, 7.5, 10.0, 12.0, $15.0 \mathrm{~mL}$ of vapour phase $/ \mathrm{mL}$ of PBS for IC50 > 6) or with positive control (SDS) for an incubation of $24 \mathrm{~h}$. Next, the medium was replaced by $200 \mu \mathrm{L}$ of working NR solution and plates were incubated at $37{ }^{\circ} \mathrm{C}$ for $3 \mathrm{~h}$. The NR solution was replaced by fixative solution for $1 \mathrm{~min}$ at room temperature, and quickly by $200 \mu \mathrm{L}$ solvent solution. The absorbance of each well was measured at $540 \mathrm{~nm}$ on a microplate reader (Biotek, ELX800) after shaking for $45 \mathrm{~min}$ at room temperature.

The relative toxicities of the various vapor phases were compared to medium control by computing the concentration of vapor phase needed to reduce the dye absorbance by $50 \%$ and so, the Inhibiting Concentration 50\% (IC50\%) was defined.

The reference cigarette allows us to define the corrected IC50 (IC50c) which is calculated as follows:

$$
\mathrm{IC} 50 \mathrm{c}=\mathrm{IC} 50_{\text {tested sample }} / \mathrm{IC} 50_{\text {reference cigarette }}
$$

With the IC50c, it is thus possible to compare data sets obtained from different groups of experiments.

\section{RESULTS}

Cell-free method development/Capillary zone electrophoresis method development

The developed cell-free method consists in analyzing GSH in a solution of PBS-trapped vapor phase. GSH can be easily analysed by different analytical methods, such as colorimetric (17), chromatographic $(18,19)$, and capillary electrophoretic methods $(20,21)$. The cigarette smokebubbled PBS matrix included several compounds with a large range of polarity, so, we require a method that would enable us to quickly analyze GSH in the presence of hydrophobic compounds (e.g., benzene). Besides, the depletion of GSH gives a wide range of product such as GSSG or GSH adducts. In order to have a specific quantitation of GSH depletion, and therefore avoid false positives, it has been decided to employ a method allowing the separation of GSH from the side products. In this case spectrometric methods have not been chosen because of lack of specificity. Moreover, a separation method between GSH and its adducts gives the opportunity for further investigations in the identification of GSH modifications by cigarette smoke.

The choice between capillary zone electrophoresis (CE) and liquid chromatography (LC) has been based on various criteria. The main difference is the run time, for the $\mathrm{CE}$ method, after the detection of the GSH, the fused silica capillary is washed with a fresh electrolyte for a few minutes to remove the vapor phase matrix. On the other hand, for the LC, the hydrophobic matrix can only be removed by application of an elution gradient followed by a step of equilibration known to be time consuming. Additionally, low solvents consumption (milliliters per day for the CE versus centiliters per day for the LC) and the use of non-hazardous solvents and reagents, give to the $\mathrm{CE}$ good qualities for a fast screening method.
In order to optimize the $\mathrm{CE}$ analysis, the effects of $\mathrm{pH}$, as well as buffer nature and concentration were explored. The results indicate $\mathrm{KH}_{2} \mathrm{PO}_{4}(50 \mathrm{mM}, \mathrm{pH} 8.1)$ to be the best electrolyte because of the good resolution, sensitivity, reproducibility and run time obtained. A capillary temperature of $40{ }^{\circ} \mathrm{C}$ was selected since it yielded the shortest migration times without peak broadening. Since the compounds of interest lack strong chromophoric properties, detection is limited to the low UV region. The buffer composition used allows measurements below $210 \mathrm{~nm}$ without interference. We also introduced an internal standard throughout the sample preparation procedure to reduce variability of peak area responses. The internal standard had to be stable, with similar chemical structure, transparently incorporated into the separation process and separable from the GSH and GSH degradation products without causing a significant increase in the overall run time of the analysis. As methionine meets the abovementioned criteria, the CE method was validated for GSH quantification using methionine as an internal standard. In our experimental conditions GSH and methionine at $\mathrm{pH} 8.1$ take a negative charge and in a normal polarity system they migrate towards the anode and are separated on the basis of their different charge density pushed by electroosmotic flow (EOF). In these conditions, the migration time for methionine and GSH were around 2.8 and $4.2 \mathrm{~min}$, respectively (Figure 1).

\section{Capillary electrophoresis method validation}

Method precision was determined measuring the repeatability, accuracy and intermediate precision (between-day precision) of corrected peak area for GSH. This parameter was defined as GSH peak area divided by methionine peak area. The repeatability of the CE method, calculated from six consecutive injections of the GSH and methionine mixture, was $0.2 \%$ for migration time and $<1 \%$ for corrected peak area. According to the literature (6), spontaneous oxidation of GSH may be anticipated with time. Therefore, the stability of the GSH solution was examined making a comparison between corrected peak area repeatability and corrected peak area time to time variation. The Fisher's test shows no peak area variation under $120 \mathrm{~min}$, so, a fresh GSH solution can be employed within $120 \mathrm{~min}$ from its preparation.

Using the data in the Table 1, correlation curves were obtained by plotting corrected peak area versus concentration, using a least square method. A lack of fit test gave a good correlation of our model $(\mathrm{P}>0.1)$ and we obtained the following mean equation:

$\left(A_{G S H} / A_{\text {methionine }}\right)=0.0314+0.00759(\mathrm{GSH})$

with a coefficient of correlation (r) of 0.9999 . Method accuracy was evaluated by recovery experiments, using the standard addition technique. Each experiment was repeated six times using the medium concentration $(300 \mu \mathrm{g} / \mathrm{mL})$. A mean recovery of $100.5 \%$ was obtained for the day 1 with a precision (Relative Standard Deviation (RSD)) of $0.4 \%$. Intermediate precision was also evaluated analyzing $\mathrm{GSH}$ solutions on three different days. We obtained a mean recovery of $99.4 \%$ with a RSD of $1.2 \%$ (Table 2 ). 

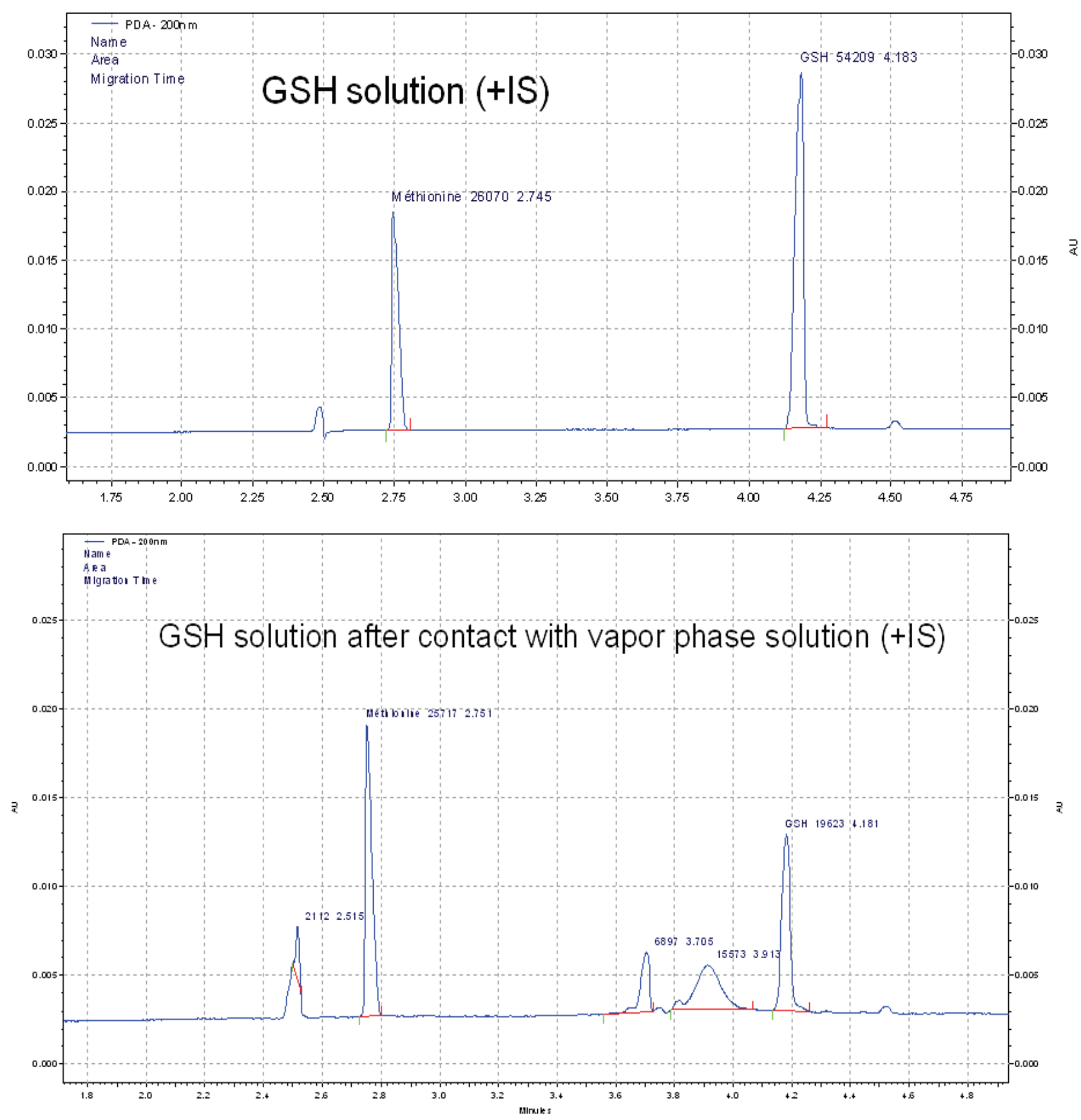

Figure 1. Comparison of electropherograms obtained before and after mixing GSH solution and PBS-trapped vapor phase.

Toxicity of the vapor phase can be evaluated by analyzing GSH solution before and after contact with the vapor phase solution (trapped in PBS).

The GSH consumption may be expressed as percentage of GSH depletion according to the following formula:

$$
\% G S H=\frac{\left(\frac{A_{G S H}}{A_{\text {methionine }}}-\frac{A_{G S H}^{S}}{A_{\text {methionine }}^{S}}\right)}{\frac{A_{G S H}}{A_{\text {methionine }}}}
$$

Where $A_{G S H}$ and $A_{\text {methionine }}$ are GSH and methionine peak areas before the reaction with the vapour phase solution,
$A_{G S H}^{S}$ and $A_{\text {methionine }}^{S}$ are GSH and methionine peak areas after the reaction.

In order to ensure that GSH depletion included from 0 to $100 \%$ with a good reproducibility, different parameters including the GSH solution concentration, volumes of vapour phase solution and GSH, the temperature and the reaction times were investigated. The best conditions were achieved with a reaction between $750 \mu \mathrm{L}$ of vapor phase solution and $250 \mu \mathrm{L}$ of GSH solution $(1 \mathrm{~g} / \mathrm{L})$ containing methionine $(2 \mathrm{~g} / \mathrm{L})$. The reaction started after thawing vapor phase-PBS aliquots $\left(5 \mathrm{~min}\right.$ at $37^{\circ} \mathrm{C}$ ). The reaction was obtained after stirring for $20 \mathrm{sec}$. In these optimized conditions the reproducibility was evaluated by comparison of GSH depletions calculated with nine different smoking 
Table 1. Linearity of the CE method.

\begin{tabular}{|c|c|c|c|c|c|c|c|c|c|}
\hline & \multicolumn{3}{|c|}{ Day $1^{\text {a }}$} & \multicolumn{3}{|c|}{ Day $2^{b}$} & \multicolumn{3}{|c|}{ Day $3^{c}$} \\
\hline & \multicolumn{2}{|c|}{ Area } & \multirow{2}{*}{$\begin{array}{c}\mathrm{GSH} / \\
\text { Methionine }\end{array}$} & \multicolumn{2}{|c|}{ Area } & \multirow{2}{*}{$\begin{array}{c}\mathrm{GSH} / \\
\text { Methionine } \\
\end{array}$} & \multicolumn{2}{|c|}{ Area } & \multirow{2}{*}{$\begin{array}{c}\text { GSH/ } \\
\text { Methionine }\end{array}$} \\
\hline & GSH & Methionine & & GSH & Methionine & & GSH & Methionine & \\
\hline \multicolumn{10}{|l|}{$50 \mu \mathrm{g} / \mathrm{mL}$} \\
\hline Inj 1 & $5,375.0$ & $13,204.0$ & 0.4 & $5,604.0$ & $13,533.0$ & 0.4 & $5,030.0$ & $13,589.0$ & 0.4 \\
\hline Inj 2 & $4,844.0$ & $12,255.0$ & 0.4 & $5,500.0$ & $13,612.0$ & 0.4 & $5,651.0$ & $13,671.0$ & 0.4 \\
\hline $\operatorname{lnj} 3$ & $5,372.0$ & $13,375.0$ & 0.4 & $4,711.0$ & $13,661.0$ & 0.3 & $5,443.0$ & $13,485.0$ & 0.4 \\
\hline Mean & $5,197.0$ & $12,944.7$ & 0.4 & $5,271.7$ & $13,602.0$ & 0.4 & $5,374.7$ & $13,581.7$ & 0.4 \\
\hline SD & 305.7 & 603.4 & 0.0 & 488.3 & 64.6 & 0.0 & 316.1 & 93.2 & 0.0 \\
\hline RSD (\%) & 5.9 & 4.7 & 1.5 & 9.3 & 0.5 & 9.7 & 5.9 & 0.7 & 5.7 \\
\hline \multicolumn{10}{|c|}{$100 \mu \mathrm{g} / \mathrm{mL}$} \\
\hline Inj 1 & $10,583.0$ & $13,379.0$ & 0.8 & $10,529.0$ & $13,418.0$ & 0.8 & $10,108.0$ & $12,690.0$ & 0.8 \\
\hline Inj 2 & $10,759.0$ & $13,488.0$ & 0.8 & $9,863.0$ & $12,357.0$ & 0.8 & $9,855.0$ & $12,814.0$ & 0.8 \\
\hline $\operatorname{lnj} 3$ & $10,002.0$ & $12,887.0$ & 0.8 & $10,656.0$ & $13,208.0$ & 0.8 & $9,908.0$ & $12,795.0$ & 0.8 \\
\hline Mean & $10,448.0$ & $13,251.3$ & 0.8 & $10,349.3$ & $12,994.3$ & 0.8 & $9,957.0$ & $12,766.3$ & 0.8 \\
\hline SD & 369.1 & 320.2 & 0.0 & 425.9 & 561.8 & 0.0 & 133.4 & 66.8 & 0.0 \\
\hline RSD (\%) & 3.8 & 2.4 & 1.4 & 4.1 & 4.3 & 1.4 & 1.3 & 0.5 & 1.9 \\
\hline \multicolumn{10}{|c|}{$200 \mu \mathrm{g} / \mathrm{mL}$} \\
\hline Inj 1 & $21,361.0$ & $13,699.0$ & 1.6 & $20,399.0$ & $11,957.0$ & 1.7 & $20,551.0$ & $14,958.0$ & 1.4 \\
\hline Inj 2 & $21,540.0$ & $13,765.0$ & 1.6 & $20,862.0$ & $12,484.0$ & 1.7 & $20,896.0$ & $13,699.0$ & 1.5 \\
\hline $\operatorname{Inj} 3$ & $21,514.0$ & $13,902.0$ & 1.5 & $21,987.0$ & $13,909.0$ & 1.6 & $20,899.0$ & $13,631.0$ & 1.5 \\
\hline Mean & $21,471.7$ & $13,788.7$ & 1.6 & $21,082.7$ & $12,783.3$ & 1.7 & $20,782.0$ & $14,096.0$ & 1.5 \\
\hline SD & 96.7 & 103.5 & 0.0 & 816.7 & $1,009.8$ & 0.1 & 200.1 & 747.3 & 0.1 \\
\hline RSD (\%) & 0.5 & 0.8 & 0.6 & 3.9 & 7.9 & 3.9 & 1.0 & 5.3 & 6.1 \\
\hline \multicolumn{10}{|c|}{$300 \mu \mathrm{g} / \mathrm{mL}$} \\
\hline Inj 1 & $31,228.0$ & $13,458.0$ & 2.3 & $32,550.0$ & $13,704.0$ & 2.4 & $32,932.0$ & $14,155.0$ & 2.3 \\
\hline Inj 2 & $30,974.0$ & $13,433.0$ & 2.3 & $32,385.0$ & $13,915.0$ & 2.3 & $30,701.0$ & $13,603.0$ & 2.3 \\
\hline Inj 3 & $30,685.0$ & $13,175.0$ & 2.3 & $32,785.0$ & $13,882.0$ & 2.4 & $30,850.0$ & $13,333.0$ & 2.3 \\
\hline Mean & $30,962.3$ & $13,355.3$ & 2.3 & $32,573.3$ & $13,833.7$ & 2.4 & $31,494.3$ & $13,697.0$ & 2.3 \\
\hline SD & 271.7 & 156.7 & 0.0 & 201.0 & 113.5 & 0.0 & $1,247.3$ & 419.0 & 0.0 \\
\hline RSD (\%) & 0.9 & 1.2 & 0.5 & 0.6 & 0.8 & 1.0 & 4.0 & 3.1 & 1.6 \\
\hline \multicolumn{10}{|c|}{$400 \mu \mathrm{g} / \mathrm{mL}$} \\
\hline Inj 1 & $42,217.0$ & $13,614.0$ & 3.1 & $42,937.0$ & $13,599.0$ & 3.2 & $42,937.0$ & $13,599.0$ & 3.2 \\
\hline Inj 2 & $42,409.0$ & $13,911.0$ & 3.0 & $43,009.0$ & $13,781.0$ & 3.1 & $43,009.0$ & $13,781.0$ & 3.1 \\
\hline Inj 3 & $42,354.0$ & $13,754.0$ & 3.1 & $42,353.0$ & $13,715.0$ & 3.1 & $42,353.0$ & $13,715.0$ & 3.1 \\
\hline Mean & $42,326.7$ & $13,759.7$ & 3.1 & $42,766.3$ & $13,698.3$ & 3.1 & $42,766.3$ & $13,698.3$ & 3.1 \\
\hline SD & 98.9 & 148.6 & 0.0 & 359.8 & 92.1 & 0.0 & 359.8 & 92.1 & 0.0 \\
\hline RSD (\%) & 0.2 & 1.1 & 0.9 & 0.8 & 0.7 & 1.1 & 0.8 & 0.7 & 1.1 \\
\hline \multicolumn{10}{|c|}{$500 \mu \mathrm{g} / \mathrm{mL}$} \\
\hline Inj 1 & $50,638.0$ & $13,274.0$ & 3.8 & $53,792.0$ & $13,945.0$ & 3.9 & $51,295.0$ & $13,397.0$ & 3.8 \\
\hline Inj 2 & $51,052.0$ & $13,435.0$ & 3.8 & $53,130.0$ & $13,798.0$ & 3.9 & $51,785.0$ & $13,501.0$ & 3.8 \\
\hline $\operatorname{Inj} 3$ & $53,700.0$ & $14,042.0$ & 3.8 & $54,730.0$ & $14,233.0$ & 3.8 & $53,717.0$ & $14,013.0$ & 3.8 \\
\hline Mean & $51,796.7$ & $13,583.7$ & 3.8 & $53,884.0$ & $13,992.0$ & 3.9 & $52,265.7$ & $13,637.0$ & 3.8 \\
\hline SD & $1,661.3$ & 405.0 & 0.0 & 804.0 & 221.3 & 0.0 & $1,280.5$ & 329.8 & 0.0 \\
\hline RSD (\%) & 3.2 & 3.0 & 0.3 & 1.5 & 1.6 & 0.2 & 2.5 & 2.4 & 0.1 \\
\hline
\end{tabular}

Day 1: $y=0.0076 x+0.0311 ; R^{2}=0.9999$;

Day 3: $y=0.0077 x+0.0066 ; R^{2}=0.9993$
Day 2: $y=0.0077 x+0.0438 ; R^{2}=0.9991$

Global (day 1,2 and 3): $y=0.00759 x+0.0314 \quad R^{2}=0.9999$ tests ( 3 smokings under 3 days) of a reference cigarette obtained on three different days. In our conditions (Table 3 ) the within-day precision, repeatability (expressed as the relative standard deviation of replicate analysis) was less than $1 \%$. The inter-assays precision, or intermediate precision was less than $2 \%$.
We also determined the vapour phase solutions stability at $-180^{\circ} \mathrm{C}$. To set up this test, the reference cigarette's vapor phase was collected, homogenized and divided in aliquot fractions before being frozen at $-180^{\circ} \mathrm{C}$. CE analyses were carried out before freezing and for each tested time: 3, 24, $168,336,504,672,1,008 \mathrm{~h}$, respectively. 
Table 2. Accuracy of the CE method. Calculated concentration (calc. conc.) in $(\mu \mathrm{g} / \mathrm{mL}) \mathrm{ppm}$.

\begin{tabular}{|c|c|c|c|c|c|}
\hline & Area GSH & Area IS & $\begin{array}{c}\text { Ratio } \\
\text { GSH/IS }\end{array}$ & $\begin{array}{l}\text { Calc. } \\
\text { conc. }\end{array}$ & $\begin{array}{c}\text { Recovery } \\
(\%)\end{array}$ \\
\hline \multicolumn{6}{|c|}{ Day 1 - Theoretical concentration $301.5(\mu \mathrm{g} / \mathrm{mL})$} \\
\hline 1 & 32463 & 13975 & 2.32 & 306.1 & 100.0 \\
\hline 2 & 33911 & 14522 & 2.34 & 303.2 & 100.6 \\
\hline 3 & 34065 & 14547 & 2.34 & 304.0 & 100.8 \\
\hline 4 & 33916 & 14601 & 2.32 & 301.5 & 100.0 \\
\hline 5 & 31491 & 13449 & 2.34 & 304.0 & 100.8 \\
\hline 6 & 34527 & 14765 & 2.34 & 303.6 & 100.7 \\
\hline \multicolumn{6}{|c|}{ Day 2 - Theoretical concentration $313.5(\mu \mathrm{g} / \mathrm{mL})$} \\
\hline 1 & 36236 & 15127 & 2.40 & 305.4 & 97.4 \\
\hline 2 & 34399 & 14133 & 2.43 & 310.4 & 99.0 \\
\hline 3 & 34037 & 14060 & 2.42 & 308.7 & 98.5 \\
\hline 4 & 34271 & 13947 & 2.46 & 313.4 & 100.0 \\
\hline 5 & 33525 & 13938 & 2.41 & 306.7 & 97.8 \\
\hline 6 & 33630 & 14070 & 2.39 & 304.7 & 97.2 \\
\hline \multicolumn{6}{|c|}{ Day 3 - Theoretical concentration $308.4(\mu \mathrm{g} / \mathrm{mL})$} \\
\hline 1 & 33277 & 14015 & 2.37 & 307.5 & 99.7 \\
\hline 2 & 34276 & 14686 & 2.33 & 302.2 & 98.0 \\
\hline 3 & 31926 & 13422 & 2.38 & 308.1 & 99.9 \\
\hline 4 & 31348 & 13225 & 2.37 & 307.0 & 99.5 \\
\hline 5 & 31885 & 13472 & 2.37 & 306.5 & 99.4 \\
\hline \multirow[t]{4}{*}{6} & 31941 & 13474 & 2.37 & 307.0 & 99.5 \\
\hline & & & & Mean & 99.4 \\
\hline & & & & SD & 1.2 \\
\hline & & & & RSD(\%) & 1.16 \\
\hline
\end{tabular}

Table 3. Repeatability and intermediate precision of the CE method.

\begin{tabular}{lcccc}
\hline Smoking & Day 1 (\%) & Day 2 (\%) & Day 3 (\%) \\
\hline 1 & 41.0 & 41.1 & 42.1 \\
2 & 40.8 & 41.1 & 42.6 \\
3 & 41.3 & 40.8 & 40.6 \\
\hline $\begin{array}{l}\text { Source of } \\
\text { variation }\end{array}$ & Variance & $\mathrm{SD}$ & $\mathrm{RSD}(\%)$ \\
\hline $\begin{array}{l}\text { Repeatability } \\
\text { Internediate } \\
\text { precision }\end{array}$ & $4.8333^{-6}$ & 0.0022 & 0.53 \\
\hline
\end{tabular}

The stability of the vapor phase PBS solution was assessed by comparison of GSH depletion percentages obtained for each time. This comparison was carried out using a multiple comparison test of NEWMAN-KeULS (22). The conclusion of this test is that vapour phase solutions are stable for 6 weeks $=1,008 \mathrm{~h}$ (Table 4).

\section{Correlation of GSH-depletion measurements with Neutral Red Uptake results}

Forty-three experimental cigarettes were analysed using both the GSH-depletion test and the Neutral Red Uptake Assay (Table 5). These cigarettes were chosen in order to have different blend styles (US and UK), filters (Cellulose Acetate and Activated Carbon), and Total Particulate Matter yields (from 2 to $19 \mathrm{mg} / \mathrm{cig}$ under ISO conditions). Figure 2 illustrates analysed IC50c values versus percentages of GSH-depletion. The results indicate a high degree of correlation between the results of both methods. A power relationship is suggested, given a correlation coefficient (r) of 0.9914 .

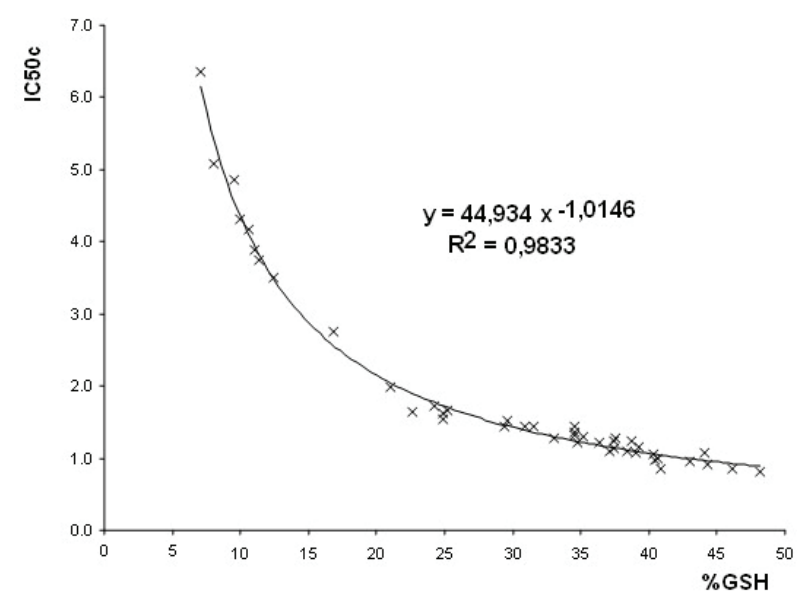

Figure 2. Relationship between analysed IC50c and GSHdepletion assay. Analysed IC 50c values were determined using Neutral Red Uptake Assay and GSH-depletion was obtained by $\mathrm{CE}$ analysis. Results of both methods were obtained with the same PBS-trapped vapor phases.

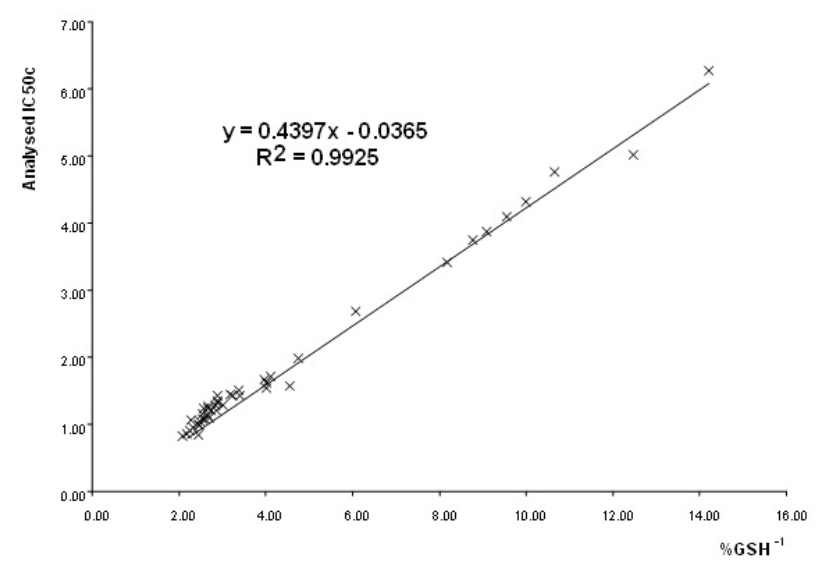

Figure 3. Linear Relationship between analysed IC50c and inverse GSH-depletion assay.

\section{DISCUSSION}

We have developed and validated a fast CE cell-free method to measure the effects of vapor phase of cigarette smoke on GSH depletion. This described method was compared with the Neutral Red Uptake Assay. The strong relationship between both methods allows the creation of a prediction model for in vitro results from the cell-free method results.

The analysed IC50c and GSH-depletion are correlated by the following equation:

$$
I C 50_{\text {corrected }}=44.934\left(\text { GSH }^{-1.0146}\right)
$$


As shown in Figure 3, this correlation can also be expressed using a linear model with inverse GSH depletion. The linearity has been proved with a correlation coefficient (r) of 0.9962 with the following equation:

$$
I C 50 c=\frac{0.4397}{G S H \%}-0.0365
$$

Figure 4 shows, for the experimental cigarettes, the relationship between the analysed IC50c (Neutral Red Uptake Assay) and calculated IC50c (GSH depletion assay), calculated from the equation 4. Very good agreement exists between measured and predicted IC50c. Hypothesis testing of parameters give a slope equal to $1(\mathrm{p}-$ value $=0.67)$ and intercept equal to $0(p$-value $=0.57)$. A measurement of influence has been carried out with a Cook's distance test. No point with high leverage has been found (all leverage $<3$ times mean leverage $(0,054)$ ).

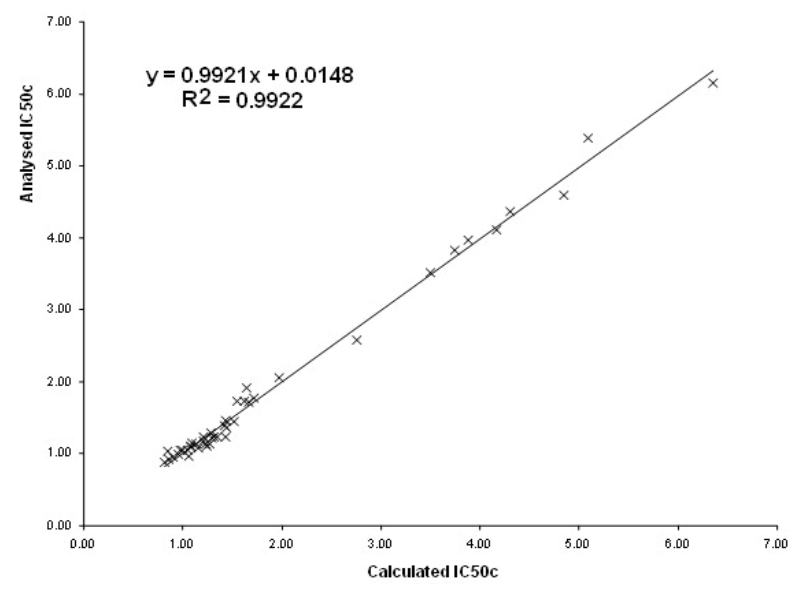

Figure 4. Linear Relationship between analysed IC50c (Neutral Red Uptake Assay) and calculated IC50c (GSH depletion assay).

Table 4. Stability of vapor phase solutions stored at $-180^{\circ} \mathrm{C}$.

\begin{tabular}{|c|c|c|c|c|c|c|c|c|}
\hline Time (h) & 0 & 3 & 24 & 168 & 336 & 504 & 672 & 1008 \\
\hline Analysis 1 & 41.3 & 41.0 & 41.5 & 41.1 & 42.1 & 40.0 & 41.8 & 40.9 \\
\hline Analysis 2 & & 40.8 & 41.5 & 41.1 & 42.6 & 41.4 & 42.3 & 42.0 \\
\hline Analysis 3 & & 41.3 & 41.2 & 40.8 & 40.6 & 41.6 & 41.8 & 41.7 \\
\hline Mean & 41.3 & 41.0 & 41.4 & 41.0 & 41.8 & 41.0 & 42.0 & 41.5 \\
\hline SD & & 0.3 & 0.2 & 0.2 & 1.0 & 0.87 & 0.29 & 0.57 \\
\hline RSD (\%) & & 0.6 & 0.4 & 0.4 & 2.5 & 2.1 & 0.7 & 1.4 \\
\hline
\end{tabular}

Multiple comparison test (NEWMAN-KEULS, 95\%): No significant differences between the eight time points have been detected.

Table 6 gives the comparison of analysed IC50c (Neutral Red Uptake Assay) and calculated IC50c (GSH depletion) for five commercial brands from the French market (ISO 'tar' yields ranged from 4 to $10 \mathrm{mg})$. The trueness of a cellfree method (or bias) is obtained by calculating the difference between analysed IC50c (Neutral Red Uptake Assay) and calculated IC50c (from GSH depletion assay). The relative bias can be expressed, as follows:

$$
\operatorname{bias}(\%)=\frac{\text { Calculated IC50c-Analysed IC50c }}{\text { Analysed IC50c }} \cdot 100
$$

The obtained relative bias, ranged between $-6 \%$ and $+5 \%$, showed a very good trueness of the cell-free method. In conclusion, the described CE cell-free method is a rapid, simple and sensitive screening test to assess the cytotoxicity of vapor phase of cigarette smoke. The obtained results (calculated IC50c) are perfectly aligned with the results obtained with the cell-method.

This rapid method is not suggested to replace in vitro assays but rather is suggested for use as a rapid and efficient screening tool in product testing. This screening method allows the generation of comparison of two products in less than a half day.

\section{REFERENCES}

1. Health Canada: Bacterial Reverse Mutation Assay for Mainstream Tobacco Smoke; Official method T-501; (2004) Version 1.1, pp. 1-19.

2. Health Canada: Neutral Red Uptake Assay for Mainstream Tobacco Smoke; Official method T-502; (2004) Version 1.1, pp. 1-18.

3. Health Canada: In vitro Micronucleus Assay for Mainstream Tobacco Smoke; Official method T-503; (2004) Version 1.1, pp. 1-17.

4. Leuchtenberger, C., R. Leuchtenberger, and I. Zbinden: Gas vapor phase constituents and SH reactivity of cigarette smoke influence lung cultures; Nature 247 (1973) 565-567.

5. Scherer, G., H.W. Hagedorn, G. Gilch, and D. Janket: Mechanistically-based tests for toxicity of tobacco smoke; CORESTA Meeting, Smoke Science/Product Technology Groups, Freiburg, Germany, 2003.

6. Guengerich, F.P. and D.C. Liebler: Enzymatic activation of chemicals to toxic metabolites; Crit. Rev. Toxicol. 14 (1985) 259-307.

7. Meister, A. and M.E.Anderson: Glutathion; Annu. Rev. Biochem. 52 (1983) 711-760.

8. Church, D.F. and W.A. Pryor: Free-radical chemistry of cigarette smoke and its toxicological implications; Environ. Health Perspect. 64 (1985)111-126. 
Table 5. Product characteristics, analysed IC50c, GSH\%, and IC50c values.

\begin{tabular}{|c|c|c|c|c|c|c|c|}
\hline Name & Blend $^{a}$ & Filter type $^{b}$ & $\begin{array}{c}\text { Ventilation } \\
(\%)\end{array}$ & $\begin{array}{c}\text { TPM } \\
\text { (mg/cig) }\end{array}$ & Analysed IC50c & $\begin{array}{c}\text { GSH depletion } \\
(\%)\end{array}$ & $\begin{array}{l}\text { Calculated } \\
\text { IC50c }{ }^{\mathrm{C}}\end{array}$ \\
\hline 1 (Reference) & USB & $\mathrm{CA}$ & 0 & 17.0 & 1.00 & 40.7 & 1.12 \\
\hline 2 & USB & $A C$ & 60 & 3.6 & 3.50 & 12.4 & 3.58 \\
\hline 3 & USB & $A C$ & 40 & 2.8 & 4.85 & 9.5 & 4.66 \\
\hline 4 & USB & $A C$ & 40 & 6.4 & 5.09 & 8.1 & 5.46 \\
\hline 5 & USB & $A C$ & 20 & 8.1 & 4.17 & 10.6 & 4.18 \\
\hline 6 & USB & $A C$ & 20 & 8.4 & 2.76 & 16.8 & 2.65 \\
\hline 7 & UKB & $A C$ & 15 & 9.2 & 1.67 & 25.2 & 1.78 \\
\hline 8 & USB & $A C$ & 15 & 9.2 & 1.65 & 22.6 & 1.98 \\
\hline 9 & UKB & CA & 15 & 9.3 & 0.85 & 46.1 & 0.99 \\
\hline 10 & UKB & $A C$ & 15 & 9.6 & 1.54 & 24.9 & 1.80 \\
\hline 11 & USB & CA & 15 & 9.7 & 0.85 & 40.9 & 1.11 \\
\hline 12 & UKB & $\mathrm{CA}$ & 15 & 10.1 & 0.96 & 43.0 & 1.06 \\
\hline 13 & USB & $A C$ & 15 & 10.5 & 3.88 & 11.0 & 4.03 \\
\hline 14 & UKB & $A C$ & 15 & 10.7 & 3.74 & 11.4 & 3.89 \\
\hline 15 & USB & $\mathrm{CA}$ & 12 & 11.0 & 0.98 & 40.5 & 1.12 \\
\hline 16 & USB & $\mathrm{CA}$ & 12 & 11.6 & 1.08 & 39.1 & 1.16 \\
\hline 17 & USB & $\mathrm{CA}$ & 12 & 11.7 & 1.23 & 37.4 & 1.21 \\
\hline 18 & USB & $\mathrm{CA}$ & 26 & 11.8 & 1.44 & 31.5 & 1.43 \\
\hline 19 & USB & $\mathrm{CA}$ & 12 & 12.0 & 0.90 & 44.4 & 1.03 \\
\hline 20 & USB & $A C$ & 12 & 12.0 & 1.43 & 30.9 & 1.46 \\
\hline 21 & UKB & $\mathrm{CA}$ & 12 & 12.1 & 1.06 & 44.1 & 1.03 \\
\hline 22 & USB & $\mathrm{CA}$ & 12 & 12.6 & 1.08 & 38.4 & 1.18 \\
\hline 23 & USB & $A C$ & 12 & 12.8 & 1.98 & 21.0 & 2.13 \\
\hline 24 & USB & $A C$ & 12 & 13.0 & 4.31 & 10.0 & 4.43 \\
\hline 25 & USB & $\mathrm{CA}$ & 19 & 13.0 & 1.52 & 29.6 & 1.52 \\
\hline 26 & USB & $\mathrm{CA}$ & 12 & 13.2 & 1.13 & 37.4 & 1.21 \\
\hline 27 & USB & $\mathrm{CA}$ & 12 & 13.4 & 0.82 & 48.2 & 0.95 \\
\hline 28 & USB & $\mathrm{CA}$ & 12 & 13.5 & 1.21 & 34.8 & 1.30 \\
\hline 29 & USB & $\mathrm{CA}$ & 12 & 13.7 & 1.27 & 37.6 & 1.21 \\
\hline 30 & USB & $\mathrm{CA}$ & 12 & 13.8 & 1.62 & 24.9 & 1.80 \\
\hline 31 & USB & $A C$ & 12 & 14.1 & 6.36 & 7.1 & 6.23 \\
\hline 32 & USB & $\mathrm{CA}$ & 12 & 14.5 & 1.29 & 35.2 & 1.29 \\
\hline 33 & USB & $\mathrm{CA}$ & 12 & 14.8 & 1.24 & 38.7 & 1.17 \\
\hline 34 & USB & $\mathrm{CA}$ & 12 & 14.8 & 1.21 & 36.4 & 1.24 \\
\hline 35 & USB & $A C$ & 12 & 14.9 & 1.71 & 24.3 & 1.85 \\
\hline 36 & USB & $\mathrm{CA}$ & 12 & 15.3 & 1.16 & 39.3 & 1.16 \\
\hline 37 & USB & $\mathrm{CA}$ & 12 & 15.6 & 1.28 & 33.1 & 1.36 \\
\hline 38 & USB & $\mathrm{CA}$ & 12 & 15.7 & 1.05 & 40.3 & 1.13 \\
\hline 39 & USB & $\mathrm{CA}$ & 12 & 15.8 & 1.09 & 37.1 & 1.22 \\
\hline 40 & USB & CA & 12 & 16.5 & 1.32 & 34.6 & 1.31 \\
\hline 41 & USB & $\mathrm{CA}$ & 12 & 16.7 & 1.43 & 29.4 & 1.53 \\
\hline 42 & USB & $\mathrm{CA}$ & 12 & 17.1 & 1.35 & 34.6 & 1.31 \\
\hline 43 & USB & $\mathrm{CA}$ & 10 & 18.6 & 1.43 & 34.6 & 1.31 \\
\hline
\end{tabular}

USB = US blend style; UKB = UK blend style

$\mathrm{CA}=$ cellulose acetate $; \mathrm{AC}=$ activated carbon

Analysed IC50c $=\left(\frac{0.4397}{\mathrm{GSH} \%}\right)+0.0365$ 
Table 6. Comparison of analysed IC50c (Neutral Red Uptake Assay) and calculated IC50c (GSH depletion) for commercial cigarettes of US blend type with cellulose acetate filter.

\begin{tabular}{l|c|c|c|c|c}
\hline Code & $\begin{array}{c}\text { ISO 'tar' } \\
\text { (mg/cig) }\end{array}$ & $\begin{array}{c}\text { IC50 } \\
\text { (analysed) }\end{array}$ & $\begin{array}{c}\text { IC50c } \\
\text { (analysed) }\end{array}$ & $\begin{array}{c}\text { IC50c } \\
\text { (calculated) }\end{array}$ & Bias (\%) \\
\hline A & 10 & 3.45 & 1.44 & 1.36 & -5.6 \\
B & 10 & 2.71 & 1.13 & 1.14 & +0.9 \\
C & 10 & 3.73 & 1.52 & 1.45 & -4.6 \\
D & 7 & 3.35 & 1.40 & 1.40 & 0.00 \\
E & 4 & 4.61 & 1.93 & 1.90 & -1.55 \\
Ref. & - & 2.39 & 1.00 & 1.04 & +4.0 \\
\hline
\end{tabular}

9. Pryor, W.A.: Biological effects of cigarette smoke, wood smoke, and the smoke from plastics: the use of electron spin resonance; Free Radic. Biol. Med. 13 (1992) 659-76.

10. Counts, M.E., F.S. Hsu, S.W. Laffoon, R.W. Dwyer, and R.H. Cox: Mainstream smoke constituent yields and predicting relationships from a worldwide market sample of cigarette brands: ISO smoking conditions; Annu. Rev. Biochem. 39 (2004) 111-34.

11. Meacher, D.M. and D.B. Menzel: Glutathione depletion lung cells by low-molecular-weight aldehydes; Cell Biol. Toxicol. 15 (1999) 163-171.

12. Reddy, S., E.I. Finkelstein, P.S.Y. Wong, A. Phung, C.E. Cross, and A. Van der Vliet: Identification of glutathione modifications by cigarette smoke; Free Radic. Biol. Med. 33 (2002) 1490-1498.

13. International Organization for Standardization: ISO 3308: Routine analytical cigarette-smoking machine Definitions and standard conditions, 2000.

14. Bombick, D.W. P.H. Ayres, and D.J.T. Doolittle: Cytotoxicity assessment of whole smoke and vapor phase of mainstream and sidestream cigarette smoke from three Kentucky reference cigarettes; Toxicol. Mech. Methods 7 (1997) 177-190.

15. Bombick D.W., B.R. Bombick, P.H. Ayres, K. Putnam, J. Avalos, M.F. Borgerding, and D.J.T. Doolittle: Evaluation of the genotoxic and cytotoxic potential of mainstream whole smoke and smoke condensate from a cigarette containing a novel carbon filter; Fundam. Appl. Toxicol. 39 (1997) 11-7.
16. Putnam, K.P., D.W. Bombick, and D.J.T. Doolittle: Evaluation of eight in-vitro assays for assessing the cytotoxicity of cigarette smoke condensate; Toxicol. In Vitro 16 (2002) 599-607.

17. Owens, I. and R.V. Belcher: A colorimetric micromethod for the determination of glutathione; Biochem. J. 94 (1965) 705-710.

18. Yoshida, T.: Determination of reduced and oxidized glutathione in erythrocytes by high-performance liquid chromatography with ultraviolet absorbance detection; J. Chromatogr. B 678 (1996) 157-164.

19. Lenton, K.J., H. Therriault, and J.R. Wagner: Analysis of glutathione disulfide in whole cells and mitochondria by postcolumn derivatisation highperformance liquid chromatography with orthophtalaldehyde; Anal Biochem. 274 (1999) 125-30.

20. Havel, K., K. Pritts, and T. Wielgos: Quantification of oxidized and reduced glutathione in plasma by micellar electrokinetic capillary electrophoresis; J. Chromatogr A 853 (1999) 215-23.

21. Carru, C., A. Zinellu, S. Sotgia, G. Marongiu, M.G. Farina, M.F. Usai, G.M. Pes, B. Tadolini, and L. Deina: Optimization of the principal parameters for the ultrarapid electrophoretic separation of reduced and oxydised glutathione by capillary electrophoresis; J. Chromatogr A. 1017 (2003) 233-238.

22. Newman, D.: The distribution of range in samples from a normal population, expressed in terms of an independent estimate of standard deviation; Biometrika 31 (1939) 20-30.

Corresponding author:

Xavier Cahours

SEITA, Imperial Tobacco Group

4, rue André Dessaux

45404 Fleury-les-Aubrais, France

E-mail: xavier.cahours@fr.imptob.com 